\title{
Health insurance coverage and health care expenditure pattern in urban Mysuru, Karnataka, India
}

\author{
Preetha Susan George ${ }^{1^{*}}$, Narayana Murthy $\mathbf{M ~ R}^{2}$, Praveen Kulkarni ${ }^{3}$ \\ ${ }^{1}$ Post Graduate Student, ${ }^{2}$ Professor and Head, ${ }^{3}$ Associate Professor, Dept. of Community Medicine, JSS Medical College, JSS Academy of \\ Higher Education and Research, Mysuru, Karnataka, India \\ *Corresponding Author: Preetha Susan George \\ Email: drsusanbejoy@gmail.com
}

\begin{abstract}
Introduction: The increasing out of pocket (OOP) expenditure due to increasing chronic diseases and inaccessibility to quality health care system, is a major threat to the income earning capacity of both rural and urban people. India is one among the countries with high OOPE with $89.2 \%$. Health insurance (HI) is a method to finance health care. So with this background, this study intends to know about health insurance coverage and health care expenditure in Urban Mysuru.

Materials and Methods: Community based cross sectional study was done in Bannimantap area, Mysuru city. Households were selected through systematic random sampling method and data was collected using pretested semi-structured questionnaire by interview method until the calculated sample size was attained. Health insurance coverage pattern and health care expenditure were collected from head of the family. Details regarding hospitalization in previous 1 year duration were collected. A sample size of 320 was calculated based on $24 \%$ prevalence (NFHS 1V). Data was analysed using SPSS-24. Descriptive statistics like percentage, mean and standard deviation were applied. Inferential statistical tests like chi-square test were applied for association.

Results: Out of the 320 households, 130 (41\%) were aware of health insurance and 190 (59\%) were not aware of health insurance. Among the $130(41 \%)$ households who were aware of health insurance, only 77 households (28\%) had health insurance, maximum being government health schemes.

Conclusions: The coverage and awareness regarding $\mathrm{HI}$ is less.
\end{abstract}

Keywords: Health care expenditure, OOPE, Health insurance, Mysuru city.

\section{Introduction}

The health indices of a country is determined with reference to the ways with which its health care gets financed. In India more than 80 percentage of health care expenditure is borne by individuals, in the form of out-of-pocket which gradually pushing them in to a vicious circle of poverty. ${ }^{1}$ Protecting the families from the financial consequences of paying for health services out of their pocket reduces the risk of them being pushed into poverty. ${ }^{2}$

Poverty and ill-health go hand in hand. In developing countries, high out of pocket payment, absence of risk pooling mechanism in health financing systems, and high level of poverty are said to result in catastrophic health expenditure. In such situations, health insurance (HI) is the need of the hour. ${ }^{2}$

As per NFHS IV data, households covered by health insurance was $23.4 \%$ in urban area. ${ }^{3}$ The public health expenditure in India (total of centre and state governments) has remained constant at approximately $1.3 \%$ of the GDP between 2008 and 2015, and increased marginally to $1.4 \%$ in 2016-17 which is less than the world average of 6\%. The National Health Policy, 2017 proposes to increase this to $2.5 \%$ of GDP by 2025 . The highest percentage of out of pocket health expenditure $(52 \%)$ is made towards medicines. ${ }^{4}$ In order to address the issues related to health care finance, Government of India launched Ayushman Bharat in 2018, which provides cashless health insurance cover up to Rs. 5 lakh per family per year, to vulnerable 10 crore families. ${ }^{9}$

Since there is paucity of published literature regarding health insurance coverage and health care expenditure in urban Mysuru, this study was undertaken in the urban field practice area of JSS Medical College, Mysuru, to assess health insurance coverage and health care expenditure.

\section{Materials and Methods}

A Community based cross sectional study was done in the urban field practice area of JSS Medical College, Mysuru. The study was done over a period of two months (SeptOct). Based on the health insurance coverage rate of $23 \%$ (as per NFHS IV data), a sample size of 320 households were calculated with $80 \%$ power, $95 \%$ confidence level and $5 \% \alpha$ error. Data was collected using systematic random sampling method. All the houses in that area were line listed initially and a sampling interval of 34 was obtained. First house was selected randomly and every $34^{\text {th }}$ house were selected from then till the sample size was attained. All households who were permanent residents and who gave informed consent were included in the study. Data was collected using pre-tested semi structured questionnaire from adult responsible respondent. Details were collected regarding various socio demographic variables, awareness regarding health insurance and the pattern of expenditure on health care over the past 1 year. Data was entered in Microsoft excel 2010 worksheet. Descriptive statistical measures like percentages was used. Inferential Statistics were applied as needed using SPSS Version 22 software. Inferential statistical test like Chi-square test was applied to find out the association and was expressed statistically significant at $\mathrm{p}$-value less than 0.05 . 


\section{Results}

Among the 320 study participants, most of them were in the age group of $45+11.8$ years. Male respondents constituted $92.5 \%$, whereas female respondents were $7.5 \%$. 92.1\% households had below poverty line (BPL) card and majority of them belonged to class IV socio-economic status according to Modified B G Prasad classification. Most of the head of the family had primary education and were involved in semiskilled occupation as shown in [Table 1].

Out of the 320 households, $130(41 \%)$ were aware of health insurance and 190 (59\%) were not aware of health insurance [Fig. 1]. Among the 130 (41\%) households who were aware of health insurance, only 77 households $(28 \%)$ had some form of health insurance (Government/ private/ community based health insurances) and 53 households (73\%) did not have any form of health insurance [Fig. 2]. Reasons for not having health insurance were most of the people didn't know whom to approach for health insurance followed by uncertainity whether they will use it or not. Among the 190 households who were not aware of any health insurance, 11(5.8\%) had health insurance cards with them without knowing the purpose of it.

Most enrolled health insurances were Government schemes (Rashtriya Swasthya Bima Yojana and Vajapeyee Arogyashree) followed by community based schemes (Yeshaswini) as seen in [Fig. 3] Among the total 320 households interviewed, $88(27.5 \%)$ had some form of health insurance. Among them $64(72.7 \%)$ were aware of the benefits under health insurance and only $48(55 \%)$ had ever used the benefit of health insurance.

Association between education of the head of family and awareness regarding health insurance was statistically significant as shown in [Table 2]. It was found that literate people were more aware of health insurance.

Association between occupation and insured were also statistically significant as shown in [Table 3]. It was seen that among the insured, majority was retired people. This in turn will help them in reducing out of pocket expenditure on medical expenses.

Among the 320 households interviewed 108 households gave history of hospitalization in the last 1 year, with a maximum hospitalization of 20 times (chronic kidney disease on dialysis). Majority of the hospitalization was for surgical reasons and for chronic disease like chronic kidney disease (CKD). Common surgical admissions were for hysterectomy, lower-segment caesarean section (LSCS), prostatectomy, cataract surgery and thyroidectomy. Medical admissions were for cerebro vascular accidents (CVA), pneumonia, diabetes mellitus and its complications, viral fevers for evaluation, and myocardial infarction.

Premium paid towards the insurance ranged between Rs.30 (Rashtriya Swasthya Bima Yojana) to Rs.5000 (Mediclaim) per annum. As shown in [Table 4]. Total health care expenditure on hospitalization was more among the uninsured when compared to insured. The difference in Out of pocket expenditure among insured and uninsured was statistically significant as tested by Mann-Whitney U Test ( $\mathrm{p}$ value $:<0.001$ ). But there was no much big difference in
Out of pocket expenditure among the insured and uninsured for out-patient expenses and the difference was not statistically significant.

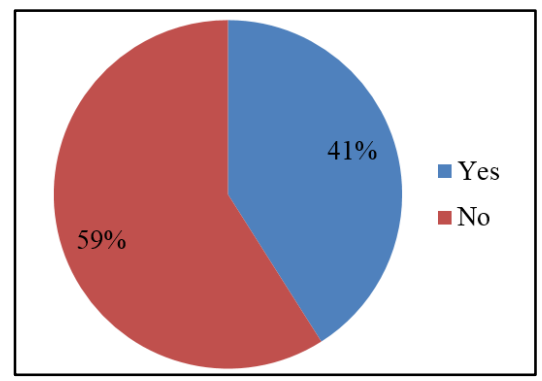

Fig. 1: Distribution of study subjects based on awareness of Health Insurance $(n=320)$

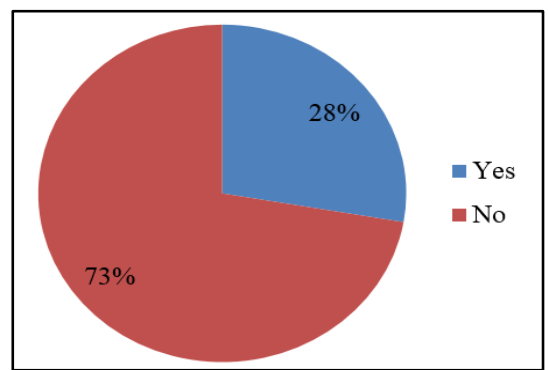

Fig. 2: Distribution of study subjects based on those having Health insurance $(n=320)$

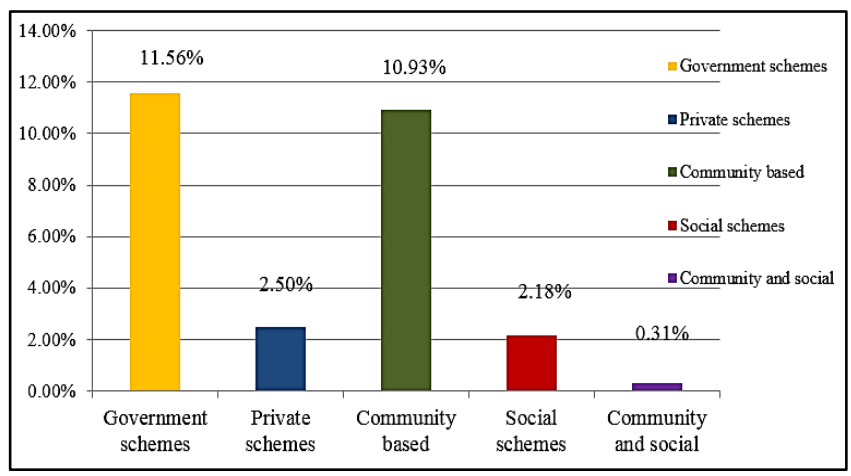

Fig. 3: Distribution of study subjects based on the types of health insurance

Table 1: Socio-demographic details of the study participants

\begin{tabular}{|l|c|}
\hline Factor & Frequency \\
\hline Educational status of head of family $(\mathrm{n}=320)$ & \\
\hline Illiterate & $31(9.7 \%)$ \\
\hline Literate & $289(90.3 \%)$ \\
\hline Occupation of the head of family $(\mathrm{n}=320)$ & \\
\hline Unskilled & $68(21.3 \%)$ \\
\hline Semiskilled/skilled & $114(35.6 \%)$ \\
\hline Self-employed/ business & $98(30.6 \%)$ \\
\hline Professional & $10(3.1 \%)$ \\
\hline Service & $4(1.3 \%)$ \\
\hline Housewife & $11(3.4 \%)$ \\
\hline Retired & $7(2.2 \%)$ \\
\hline Unemployment & $8(2.5 \%)$ \\
\hline
\end{tabular}


Table 2: Association of socio- demographic variable to awareness of health insurance

\begin{tabular}{|c|c|c|c|c|}
\hline Category & $\begin{array}{c}\text { Awareness of } \\
\text { Health insurance }\end{array}$ & $\begin{array}{c}\text { Not aware of } \\
\text { Health insurance }\end{array}$ & Chi square value & P value \\
\hline Type of family & $74(37.4 \%)$ & $124(62.6 \%)$ & & \\
Nuclear & $56(45.9 \%)$ & $66(54.1 \%)$ & 2.276 & 0.131 \\
Joint & & & & \\
\hline Education of head of & $7(22.6 \%)$ & $24(77.4 \%)$ & & \\
the family & $123(42.6 \%)$ & $166(57.4 \%)$ & 4.633 & \\
Illiterate & $9(52.9 \%)$ & $8(47.1 \%)$ & & $0.031^{*}$ \\
Literate & $41(51.9 \%)$ & $38(48.1 \%)$ & & \\
\hline Socio economic status & $33(40.2 \%)$ & $49(59.8 \%)$ & & \\
Class 1 & $34(32.1 \%)$ & $72(67.9 \%)$ & & \\
Class II & $13(36.1 \%)$ & $23(63.9 \%)$ & & \\
Class III & & & \\
Class IV & & & \\
Class V & & & \\
\hline
\end{tabular}

*p -value was found to be significant

Table 3: Association of socio- demographic variable to Insured

\begin{tabular}{|c|c|c|c|c|}
\hline Category & $\begin{array}{c}\text { Have health } \\
\text { insurance }\end{array}$ & $\begin{array}{c}\text { Doesn't have } \\
\text { health insurance }\end{array}$ & Chi square & P value \\
\hline $\begin{array}{c}\text { Type of family } \\
\text { Nuclear } \\
\text { Joint }\end{array}$ & $\begin{array}{l}51(25.8 \%) \\
37(30.3 \%)\end{array}$ & $\begin{array}{c}147(74.2 \%) \\
85(69.7 \%)\end{array}$ & 0.791 & 0.374 \\
\hline $\begin{array}{l}\text { Education of head of } \\
\text { family } \\
\text { Illiterate } \\
\text { Literate }\end{array}$ & $\begin{array}{c}5(16.1 \%) \\
83(28.7 \%)\end{array}$ & $\begin{array}{c}26(83.9 \%) \\
206(71.3 \%)\end{array}$ & 2.226 & 0.136 \\
\hline $\begin{array}{cl}\text { Occupation } \\
\text { - } & \text { Unskilled } \\
\text { - } & \text { Semiskilled/ } \\
& \text { skilled/ } \\
\text { - } & \text { Self employed/ } \\
& \text { business } \\
\text { - } & \text { Professional } \\
\text { - } & \text { Gov. service } \\
\text { - } & \text { House wife } \\
\text { - } & \text { Retired } \\
\text { - } & \text { Unemployed }\end{array}$ & $\begin{array}{c}14(20.6 \%) \\
33(28.9 \%) \\
30(30.6 \%) \\
2(20.0 \%) \\
1(25.0 \%) \\
2(18.2 \%) \\
6(85.7 \%) \\
0(0.0 \%)\end{array}$ & $\begin{array}{l}54(79.4 \%) \\
81(71.1 \%) \\
68(69.4 \%) \\
8(80.0 \%) \\
3(75.0 \%) \\
9(81.8 \%) \\
1(14.3 \%) \\
8(100 \%)\end{array}$ & 15.755 & 0.018\# \\
\hline
\end{tabular}

\# Fisher exact test

Table 4: Total health care expenditure for those insured and non- insured

\begin{tabular}{|l|c|c|c|c|}
\hline Categories & $\begin{array}{c}\text { Insured/ Non- } \\
\text { insured }\end{array}$ & Numbers & $\begin{array}{c}\text { Median cost expenditure (in } \\
\text { Rs. In range) }\end{array}$ & p value \\
\hline $\begin{array}{l}\text { IP expenditure } \\
\text { (median, IQR) }\end{array}$ & Insured & 47 & $5000(3500-10,000)$ & $<0.001^{*}$ \\
\hline OP expenditure & Non- insured & 58 & $12,000(800-25,000)$ & 0.686 \\
& Insured & 70 & $525(300-800)$ & \\
\hline
\end{tabular}

*p- value was found to be significant

Mann- Whitney U test

\section{Discussion}

In our study $41 \%$ of the respondents were aware of health insurance. This finding was similar to the findings by Hugara et $\mathrm{al}^{2}{ }^{2}$ a study done in rural mysuru, where awareness about health insurance among the respondents were $42 \%$. This finding shows that there was no much difference between the awareness among those in rural and urban area, as most of the time much attention is given to rural area. 190 households (59\%) didn't have any type of 
health insurance as $64 \%$ of the respondents didn't know whom to approach for health insurance.

Among the respondents who were aware of health insurance, only $28 \%$ had some form of health insurance. The respondents who were aware of health insurance and not insured believed that it's a waste of money as they were not sure of the utilisation of the scheme.

Awareness of health insurance was dependent on education, with literate people being more aware of health insurance. This finding was similar to the findings in the study by Pooja Kansra et al. ${ }^{7}$ Majority of the health insurance was Government schemes (RSBY) as most of them belonged to BPL category followed by community based schemes (Yeshaswini). Majority of them got to know about health insurance from relatives and mass media. Most of the nuclear families were fully covered. But in case of joint families partial coverage was noticed. It was mainly due to the rules of the schemes, like as in ESI where it covers only the blood relatives of the employee.

Among the households who had health insurance 77.6\% were aware of the benefits under the health insurance scheme. Some families had health insurance card which was not utilised and expired. Lack of utilisation demotivated them from renewing the card. Majority were unaware of the services that can be availed under the schemes. The respondents felt that if they did not fall sick they were unnecessarily paying a high amount as premium which was wasted.

In the present study it was found that the median cost of OP expenditure was high among non- insured, as these OP expenses were not covered under health insurance schemes. Since chronic diseases are on the rise, high OOP spending on medications and laboratory testing were noted. This finding was similar to the findings by Upendra et al study. ${ }^{8}$ The difficulty in bearing increased cost on medication lead to nonadherence to treatment which in turn lead to poor health outcomes and it continues as a viscous cycle.

The awareness regarding available health insurance should be increased in urban area also, as urban population are on the rise and it is estimated that by 2031, there would be around 600 million people living in urban India. ${ }^{9}$ Awareness can be increased by preventing the delay in government formalities for providing ID cards and increasing the number of network hospitals. ${ }^{2}$

\section{Recommendation}

Most of the respondents opined that Government should come up with a clear cut health insurance scheme with proper awareness regarding the facilities available inside the schemes. They also emphasised on giving public awareness as to whom to approach to avail these services.

\section{Limitation of the study}

Expenses towards the health events were collected retrospectively and the information provided might vary a little because of recall bias. Collective OOP payments for other items like travel, food and informal payments were not taken into account while assessing out of pocket expenditure since it was a retrospective study.

\section{Acknowledgment}

We acknowledge all the participants who have given information for this study.

\section{Source of funding}

None.

\section{Conflict of interest}

None.

\section{References}

1. Bawa DSK. Awareness and Willingness to Pay for Health Insurance: An Empirical Study with Reference to Punjab India. Int J Humanit Soc Sci 2011;1(7):100-08.

2. Siddalingappa H, Harshith GC, Murthy MN, Kulkarni P, Kumar DS. Health insurance coverage and healthcare expenditure pattern in rural Mysore. Indian J Med Specialities 2015;6(4):151-4.

3. National Family Health Survey [Internet]. [cited 2019 Mar 27]. Available from: http://rchiips.org/nfhs/factsheet_nfhs-4.shtml

4. Rao N. Who Is Paying for India's Healthcare. The Wire. 2018.

5. Singh P, Shukla T. Penetration of Health Insurance in India: Reality or Mirage? Res J Business Manag 2018;08.

6. Kansra P, Gill HS. Occupational Differences in the Awareness and Perception of Health Insurance of Workers Employed in Urban Informal Sector of Punjab. J Health Manag 2016;18(3):410-23.

7. Bhojani U, Thriveni BS, Devadasan R, Munegowda CM, Devadasan N, Kolsteren P, et al. Out-of-pocket healthcare payments on chronic conditions impoverish urban poor in Bangalore, India. BMC Public Health 2012;12(1):990.

8. Tripathy RM. Public health challenges for universal health coverage. Indian J Public Health 2014;58(3):156.

9. Bakshi H, Sharma R, Kumar P. Ayushman bharat initiative. What we stand to gain or lose!. Indian J Community Med official publication of Indian Assoc Preventive Soc Med 2018;43(2):63.

10. Garg S. Universal health coverage in India: Newer innovations and the role of public health. Indian J Public Health 2018;7;62(3):167.

How to cite this article: George, PS Murthy NMR,
Kulkarni P. Health insurance coverage and health care
expenditure pattern in urban Mysuru, Karnataka, India. $J$
Community Health Manag 2019;6(3):82-5.

